\title{
Use of ACE-Inhibitors in Serbia in 2009 and 2010
}

\author{
Dajana M. Perić ${ }^{1}$, Dragana S. Milijaševićn ${ }^{1}$ Nataša Z. Tomićn \\ Aleksandar D. Knežević ${ }^{2}$ Nina R. Bukumirović ${ }^{1}$, Boris Ž. Milijašević ${ }^{1}$ \\ ${ }^{1}$ Department of Pharmacology, Toxicology and Clinical Pharmacology, Faculty of Medicine, \\ University of Novi Sad, Novi Sad, Serbia; \\ ${ }^{2}$ Emergency Center, Clinical Center of Vojvodina, Novi Sad, Serbia.
}

\section{SUMMARY}

Introduction Cardiovascular diseases (CVD) are the most frequent cause of morbidity and mortality in many countries as well as in our country. That explains why medications for the treatment of CVD are the most used group of drugs. The aim of this study was to analyze the consumption of ACE-inhibitors in Serbia and Norway during 2009 and 2010.

Material and methods The data about the use of ACE-inhibitors in Serbia and Norway in 2009 and 2010 were taken from the Agency for Drugs and Medical Devices of the Republic of Serbia and from the site of Norwegian Institute of Public Health.

Results Use of drugs of first choice in the treatment of hypertension in Serbia was very uneven, where the consumption of ACE-inhibitors was dominant. Opposed to this condition, the consumption of the first choice antihypertensive drugs was very balanced in Norway. During both analyzed years large part of consumption of ACE-inhibitors was taken by more expensive drugs in Serbia, as fosinopril, cilazapril and quinapril. In Norway in the observed period, dominated the consumption of cheaper drugs such as enalapril and ramipril. The situation is similar when it comes to fixed combination of diuretics and ACE-inhibitors. In Norway dominated the fixed combination of diuretics and cheaper ACE-inhibitors like enalapril and lisinopril. However, in Serbia, we have large consumption fixed combinations of diuretics with expensive ACE-inhibitors, such as cilazapril and fosinopril.

Conclusions In both countries, ACE-inhibitors and their fixed combination with diuretics are most frequently used drugs within the group of drugs which is used for treatment of CVD in Serbia in 2009 and 2010. The amount and structure of the utilized ACE-inhibitors in Serbia is different from the amount and structure of the utilized ACE inhibitors in Norway. From pharmacoeconomic point of view, high consumption of expensive ACE-inhibitors (plain and fixed combination with diuretics) in 2009 and 2010 in Serbia resulted in the higher spending of funds.

Keywords: pharmacoepidemiology, ACE-inhibitors, cardiovascular system, hypertension 


\section{INTRODUCTION}

Cardiovascular disease (CVD) and kidney disease are the most common cause of morbidity and mortality in industrialized countries [1]. In 2008, the rate of mortality from CVD in Serbia stood at $55.8 \%$ which ranks Serbia among the countries with the highest cardiovascular mortality [2]. It is therefore understandable why drugs which are in use for the treatment of cardiovascular disease (group $\mathrm{C}$ according to ATC classification) are the most frequently used group of drugs. Besides, consumption of drugs from the $\mathrm{C}$ group has steadily increased in Serbia. In 2004,the total consumption of drugs amounted to $30.54 \%$, while in 2008 it amounted to $38.89 \%$ [2, 3]. In relation to all drugs of $\mathrm{C}$ group, in the world, and in our country angiotensin converting enzyme inhibitors (ACE-inhibitors), drugs used in treatment of hypertension and cardiac insufficiency, occupy an important place $[4,5$, $6]$.

Hypertension is a major risk factor for the development of other cardiovascular diseases including coronary artery disease, stroke, heart failure and end stage of renal disease $[4,7]$. According to the World Health Organization (WHO) and International Society of Hypertension (ISH) in 2003 was estimated that hypertension occurs in $4-5 \%$ of cases compared to the more global disease, and it is widespread in both developing and developed countries. Globally, complications associated with hypertension are the third in a row in terms of mortality. WHO estimates that the number of people diagnosed with hypertension will be increased by $60 \%$ over the next few years [5]. Modern approach in treatment of hypertension is based on application of five groups of drugs: diuretics, $\beta$-blockers, ACE-inhibitors, calcium channel blockers and angiotensin II receptor antagonists (ARBs). Also, in the treatment of hypertension is recommand use of fixed combinations of ACE - inhibitors and angiotensin receptor blockers with diuretics and calcium channel blockers $[4,5,8]$.

The mechanism of action of ACEinhibitors takes place through the renin-angiotensin-aldosterone system (RAAS). Hemodynamic effects of ACE-inhibitors are caused by reduction levels of angiotensin II and aldosterone, and by increasing levels of bradykinin. Bradykinin have vasodilator and hypotensive actions. These drugs reduce tension at the level of the arteries and veins and relieve the heart by reducing afterload and preload. As a result there is a decrease in systolic and diastolic blood pressure [9]. Adverse effects of ACE-inhibitors include: hypotension, dry cough, hyperkalaemia, renal failure, fetal anomalies [9]. Indications for the benefit of ACE-inhibitors include: hypertension, congestive heart failure, myocardial infarction, ischemic heart disease, stroke [4].

The benefits of ACE-inhibitors over the other antihypertensives are reflected in their increasing protective effect on the renal blood vessels in patients with diabetes mellitus. They have multiple effects on kidneys, including reducing of renovascular resistance, and also slowdown deterioration of renal function that occurs in diabetic nephropathy and thus prevents the progression of microalbuminuria in proteinuria [10]. ACE-inhibitors can be used in combination with a diuretic and with calcium channel blockers. These drugs can be applied in fixed combination with diuretics because, thiazide diuretics cause decrease of potassium and ACE-inhibitors potassiumsparing. In this way, it avoids the appearance of hypo or hyperkalaemia in the application of each of these drugs individually [4]. On the other hand, in primary hypertension, ACEinhibitors do not show a significant advantage because they both reduce blood pressure, like other antihypertensive drugs of first choice. The advantage of ACE-inhibitors could be seen in terms of their kinetics, because most of these drugs are applied once a day [8]. Seen from pharmacoeconomic aspect, the structure of ACE-inhibitors which are consumed in Serbia in recent years is not rational because the drugs of this group were much more in use than other drugs of first choice in the treatment of arterial hypertension. We can also notice that the newer and more expensive preparations have priority, regardless they do not show significant efficacy compared to older and cheaper ACE-inhibitors [3, 11, 12, 13].

\section{THE AIM}

The aim of this study was to analyze the consumption of ACE-inhibitors in Serbia during 2009 and 2010 from pharmacotherapeutic and pharmacoeconomic point of view, as well as comparing that with consumption in Norway, which has developed pharmacotherapeutic 
practice.

\section{MATERIAL AND METHODS}

The data about the use of ACE-inhibitors in Serbia in 2009 and 2010 were taken from the Agency for Drugs ans Medical Devices of the Republic of Serbia $[14,15]$. The data of drug consumption in Norway were taken from the official site of the Norwegian Institute of Public Health [16]. Analysis of the consumption of drugs was done from the point of social perspective and there were no influence of any factors or any interest group. The amount of used drugs are expressed in the number of defined daily doses (DDD) per 1000 inhabitants per day (DDD/1000 inh/day).

Internationally recognized and widely accepted methodology in the study of drug use is based on the concept of anatomicaltherapeutic-chemical classification of drugs (ATC) and defined daily doses. According to the ATC classification the drugs that we use in treatment of cardiovascular diseases belong to the $\mathrm{C}$ group, whereas drugs that act on the renin angiotensin system are belonging to a group of C09. Further analyzed in C09A group, we have monocomponent products, and the combination of ACE-inhibitors with diuretics which belong to the C09B group. In order to facilitate comparison of the intensity of use of certain drugs in time and in different geographical areas scientes created a separate statistical unit of measurement of use of drugs, labeled as defined daily doses (DDD). This unit is independent of price, size, packaging, protected names of individual manufacturers and even from the pharmaceutical dosage form. The concept of DDD offered as a statistical unit of use the agreed amount of drug that is commonly used for the most common indication. DDD is defined, whenever its possible, in weight units (or units of activity, for example, insulin). When it is impractical or even impossible to express the weight of the DDD, like in case with combined preparations, for the monitoring unit is taken dosage form (tablets, capsules, ampoules) and then it is referred to as effective dose (ED) [17].

\section{RESULTS}

Consumption of drugs for the treatment of cardiovascular diseases in Serbia in 2009 and 2010 year was sizeable. Drugs of the $\mathrm{C}$ group in 2009 year accounted for $35.21 \%$ of total drugs consumed in Serbia, and 2010, share of these drugs in the total consumption was even higher and amounted to $39.82 \%$. In Norway, consumption of drugs for the treatment of cardiovascular disease observed in this two years was lower than in Serbia, amounting to about $31 \%$, without trend of increasing consumption.

Comparative review of drug of first choice in the treatment of hypertension in Serbia and Norway in 2009 and 2010 are presented in Graphs 1 and 2.
Graph 1. Comparative review of drug of first choice in the treatment of hypertension in Serbia and Norway in 2009
C03 - diuretics;

C07 - beta blocking agents; C08 - calcium channel blockers; C09A+B - ACE inhibitors, plain and ACE inhibitors, combinations; C09C+D - angiotensin II receptor antagonists, plain and angiotensin II receptor antagonists, combinations

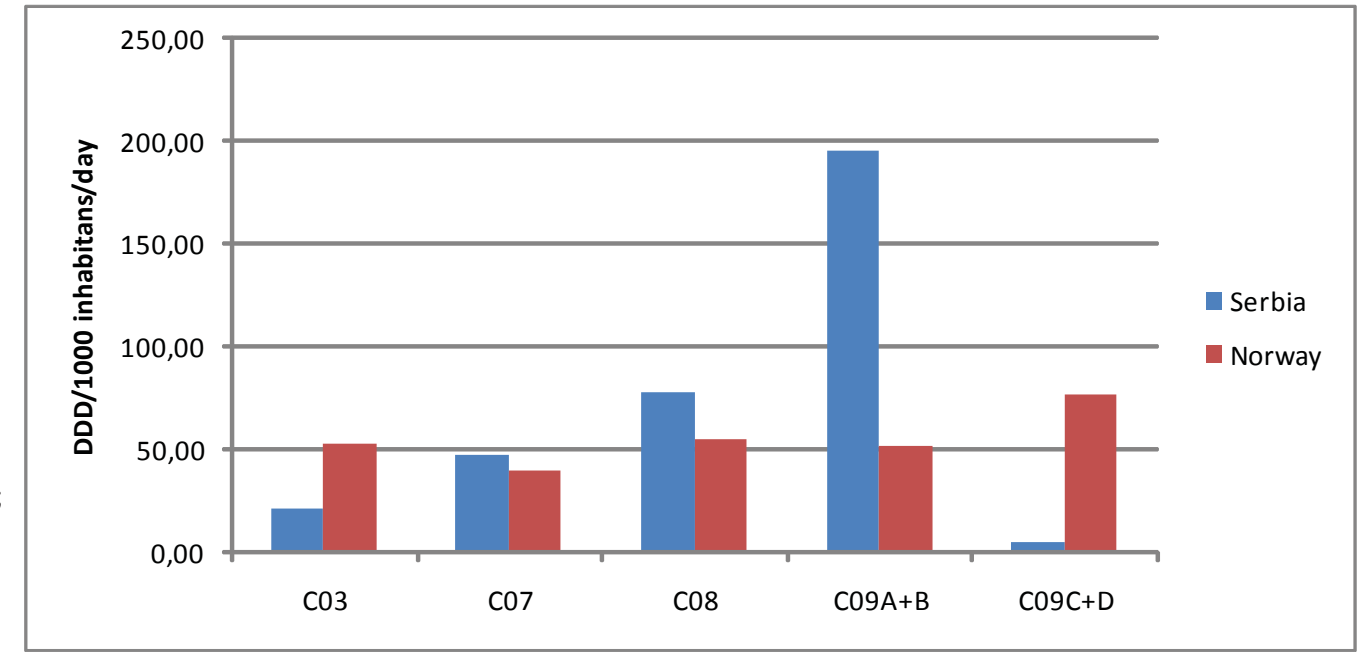

In the detailed analysis of the consumption of drugs from group $\mathrm{C}$ in the considered period in Serbia, it was found that the highest consumption in 2009 and 2010 was achieved in the group of drugs that act on the renin angiotensin aldosterone system (C09 group) and it was nearly half of all drugs that are used in the treatment of cardiovascular 


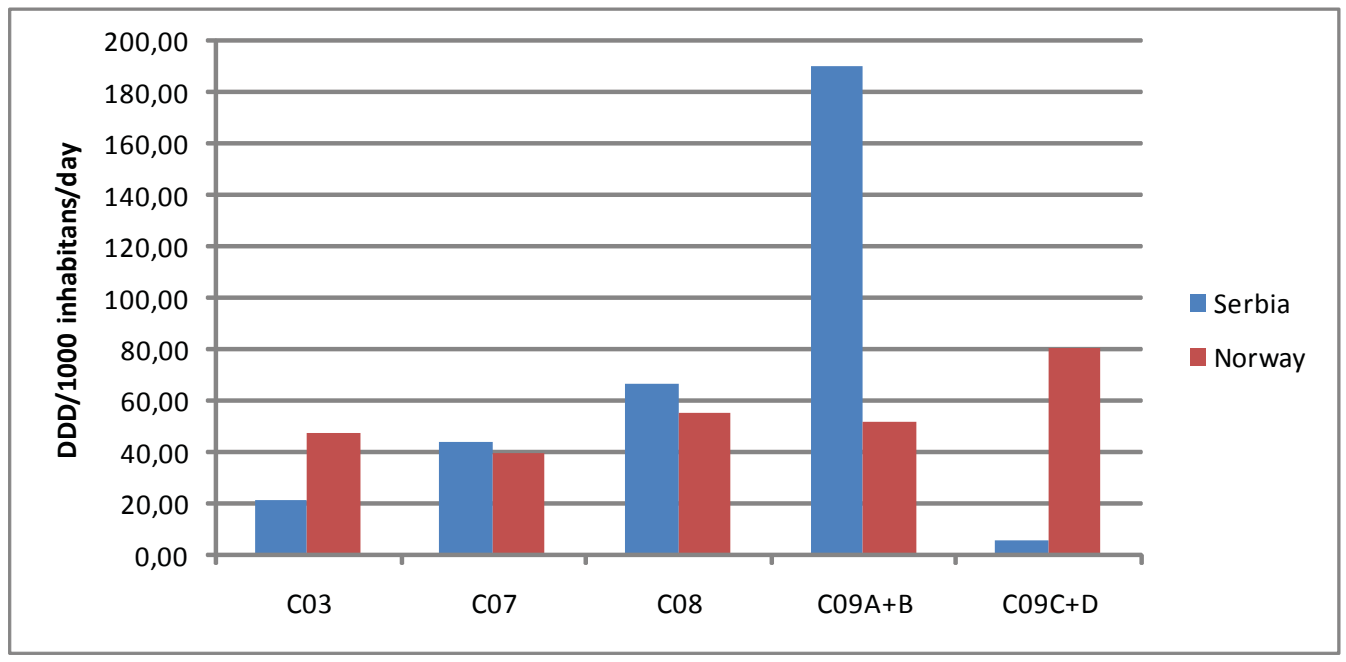

diseases. The situation in Norway is different and consumption of drugs group C09 during these two years was about $32 \%$ which is less than one third of the total consumed drugs in the group C.

Comparative review of drug which is acting on the renin angiotensin aldosterone system (group C09) in Serbia and Norway in 2009 and 2010 is presented in Table 1.

Consumption of ACE-inhibitors (plain) in the Republic of Serbia and Norway in the years 2009 and 2010 is presented in Table 2 .

Comparative overview consump-

\begin{tabular}{|c|c|c|c|c|c|c|c|c|c|}
\hline \multirow{3}{*}{$\begin{array}{l}\text { ATC } \\
\text { group }\end{array}$} & \multirow{3}{*}{$\begin{array}{l}\text { Pharmacotherapeutic } \\
\text { group }\end{array}$} & \multicolumn{4}{|c|}{ Serbia } & \multicolumn{4}{|c|}{ Norway } \\
\hline & & \multicolumn{2}{|c|}{2009} & \multicolumn{2}{|c|}{2010} & \multicolumn{2}{|c|}{2009} & \multicolumn{2}{|c|}{2010} \\
\hline & & DDD & $\%$ & DDD & $\%$ & DDD & $\%$ & DDD & $\%$ \\
\hline CO9 & $\begin{array}{l}\text { Drugs acting on the } \\
\text { RAA system }\end{array}$ & 200.42 & 100.00 & 196.71 & 100.00 & 128.66 & 100.00 & 133.05 & 100.00 \\
\hline $\begin{array}{l}\text { C09A } \\
+ \\
\text { C09B } \\
\end{array}$ & ACE inhibitors & 195.23 & 97.41 & 190.39 & 96.78 & 51.64 & 40.14 & 51.86 & 39.98 \\
\hline CO9A & ACE inhibitors - plain & 164.46 & 82.06 & 163.10 & 82.91 & 45.02 & 34.99 & 45.23 & 33.99 \\
\hline C09B & $\begin{array}{l}\text { ACE inhibitors - } \\
\text { combinations* }^{*}\end{array}$ & 30.77 & 15.35 & 27.29 & 13.87 & 6.62 & 5.15 & 6.63 & 4.98 \\
\hline $\begin{array}{l}\text { CO9C } \\
+ \\
\text { CO9D } \\
\end{array}$ & $\begin{array}{l}\text { Angiotensin II antago- } \\
\text { nists }\end{array}$ & 5.19 & 2.59 & 6.32 & 3.21 & 77.02 & 59.86 & 81.16 & 61.00 \\
\hline $\mathrm{CO9C}$ & $\begin{array}{l}\text { Angiotensin II antago- } \\
\text { nists - plain }\end{array}$ & 5.07 & 2.53 & 6.14 & 3.12 & 41.80 & 32.49 & 44.24 & 33.25 \\
\hline CO9D & $\begin{array}{l}\text { Angiotensin II antago- } \\
\text { nists - combinations** }\end{array}$ & 0.12 & 0.06 & 0.18 & 0.09 & 35.22 & 27.37 & 36.92 & 27.75 \\
\hline
\end{tabular}

tion of ACE-inhibitors (combination) (group C09B) in Serbia and Norway in 2009 and 2010 is presented in Table 3 .

\section{DISCUSSION}

The contemporary approach to pharmacotherapeutic treatment of high blood pressure is based on five groups of drugs. These includes:
Graph 2. Comparative review of drug of first choice in the treatment of hypertension in Serbia and Norway in 2010

C03 - diuretics;

C07 - beta blocking agents; C08 - calcium channel blockers; C09A+B - ACE inhibitors, plain and ACE inhibitors, combinations; C09C+D - angiotensin II receptor antagonists, plain and angiotensin II receptor antagonists, combinations

Table 1. Comparative review of drug acting on the renin angiotensin aldosterone system (group C09) in Serbia and Norway in 2009 and 2010

DDD - DDD/1000 inh/day RAA - renin angiotensin aldosteron

* - ACE inhibitors and diuretics ** - Angiotensin II antagonists and diuretics 
Table 2. Comparative overview consumption of ACE inhibitors plain (group C09A) in Serbia and Norway in 2009 and 2010

DDD - DDD/1000 inh/day

Table 3. Comparative overview consumption of ACE inhibitors a combination (group C09B) in Serbia and Norway in 2009 and 2010

DDD - DDD/1000 inh/day

* - ACE inhibitors and diuretics consumption of some, of these five groups of antihypertensive drugs [8].

But, the situation in Serbia is differente. Consumption of these five groups of drugs is uneven and consumption of ACE- inhibitors convincingly is on the first place. In 2009 and 2010 in Serbia the most aplied were ACE-inhibitors. Consumption of ACEinhibitors in 2009 was 195.23 and in 2010 it was $190.39 \mathrm{DDD} / 1000 \mathrm{inh} /$ day. On the sec-

\begin{tabular}{|c|c|c|c|c|c|c|c|c|c|}
\hline \multirow{3}{*}{$\begin{array}{l}\text { ATC } \\
\text { group }\end{array}$} & \multirow{3}{*}{$\begin{array}{l}\text { Pharmacotherapeutic } \\
\text { group }\end{array}$} & \multicolumn{4}{|c|}{ Serbia } & \multicolumn{4}{|c|}{ Norway } \\
\hline & & \multicolumn{2}{|c|}{2009} & \multicolumn{2}{|c|}{2010} & \multicolumn{2}{|c|}{2009} & \multicolumn{2}{|c|}{2010} \\
\hline & & DDD & $\%$ & DDD & $\%$ & DDD & $\%$ & DDD & $\%$ \\
\hline CO9A & ACE inhibitors - plain & 164.46 & 100.00 & 163.10 & 100.00 & 45.02 & 100.00 & 45.23 & 100.00 \\
\hline C09AA01 & captopril & 6.40 & 3.89 & 3.90 & 2.39 & 0.74 & 1.64 & 0.66 & 1.46 \\
\hline C09AA02 & enalapril & 88.40 & 53.75 & 80.96 & 49.64 & 10.97 & 24.37 & 11.08 & 24.50 \\
\hline CO9AA03 & lisinopril & 2.31 & 1.40 & 3.34 & 2.05 & 6.46 & 14.35 & 6.20 & 13.71 \\
\hline C09AA04 & perindopril & 0.84 & 0.51 & 1.06 & 0.65 & - & - & - & \\
\hline C09AA05 & ramipril & 22.51 & 13.69 & 34.17 & 20.95 & 26.83 & 59.60 & 27.27 & 60.29 \\
\hline C09AA06 & quinapri & 2.62 & 1.59 & 2.06 & 1.26 & - & - & - & - \\
\hline C09AA08 & cilazapril & 18.01 & 10.95 & 13.06 & 8.01 & - & - & - & - \\
\hline C09AA09 & fosinopril & 23.36 & 14.20 & 24.53 & 15.04 & - & - & - & - \\
\hline C09AA10 & trandolapril & - & - & - & - & 0.02 & 0.04 & 0.02 & 0.04 \\
\hline C09AA15 & zofenopril & 0.01 & 0.01 & 0.02 & 0.01 & - & - & - & - \\
\hline
\end{tabular}

ond place were calcium channel blockers, whose consumption was three times lower in comparison to ACE-inhibitors. At the third position were beta blockers with four times lower consumption, while the fourth position occupy diuretics with nine times less applied consumption in relation to ACE-inhibitors. Used of ACE-inhibitors in Serbia in 2009 and 2010 was neglected. Using these five groups of drugs in the observed period in Norway was balansed. In these two years the lower consumption had beta blockers and it ranged from approximately $40 \mathrm{DDD} / 1000 \mathrm{inh} /$ day. Angiotensin receptor blockers were most applied and their consumption ranged about 78 $\mathrm{DDD} / 1000 \mathrm{inh} /$ day for (Graphs 1 and 2).

In Serbia, the consumption of ACEinhibitors in 2010 was four times higher than in Norway (Graph 2). Opposed to this condition, the consumption of angiotensin receptor blockers in Norway was very large and the participation of drugs from this group was about $60 \%$, while in Serbia it was only about $3 \%$ of total drugs consumed in Group C09. A similar

\begin{tabular}{|c|c|c|c|c|c|c|c|c|c|}
\hline \multirow{3}{*}{$\begin{array}{l}\text { ATC } \\
\text { group }\end{array}$} & \multirow{3}{*}{$\begin{array}{l}\text { Pharmacotherapeutic } \\
\text { group }\end{array}$} & \multicolumn{4}{|c|}{ Serbia } & \multicolumn{4}{|c|}{ Norway } \\
\hline & & \multicolumn{2}{|c|}{2009} & \multicolumn{2}{|c|}{2010} & \multicolumn{2}{|c|}{2009} & \multicolumn{2}{|c|}{2010} \\
\hline & & DDD & $\%$ & DDD & $\%$ & DDD & $\%$ & DDD & $\%$ \\
\hline C09B & $\begin{array}{l}\text { ACE inhibitors - } \\
\text { combinations* }\end{array}$ & 30.77 & 100.00 & 27.29 & 100.00 & 6.62 & 100.00 & 6.51 & 100.00 \\
\hline С09BA02 & $\begin{array}{l}\text { enalapril, } \\
\text { hydrochlortiaside }\end{array}$ & 12.00 & 39.00 & 2.93 & 10.74 & 3.81 & 57.55 & 3.79 & 58.22 \\
\hline С09ВА03 & $\begin{array}{l}\text { lisinopril, } \\
\text { hydrochlortiaside }\end{array}$ & 0.08 & 0.26 & 1.13 & 4.14 & 2.81 & 42.45 & 2.72 & 41.78 \\
\hline С09BA04 & $\begin{array}{l}\text { perindopril, } \\
\text { indapamide }\end{array}$ & - & - & 0.01 & 0.04 & & - & - & \\
\hline С09BA05 & $\begin{array}{l}\text { ramipril, } \\
\text { hydrochlortiaside }\end{array}$ & 4.10 & 13.32 & 7.38 & 27.04 & & - & - & \\
\hline С09BA06 & $\begin{array}{l}\text { quinapril, } \\
\text { hydrochlortiaside }\end{array}$ & 1.31 & 4.26 & 1.38 & 5.06 & - & - & - & - \\
\hline С09BA08 & $\begin{array}{l}\text { cilazapril, } \\
\text { hydrochlortiaside }\end{array}$ & 6.88 & 22.36 & 5.77 & 21.14 & & 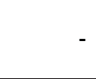 & - & \\
\hline С09BA09 & $\begin{array}{l}\text { fosinopril, } \\
\text { hydrochlortiaside }\end{array}$ & 6.40 & 20.80 & 8.70 & 31.88 & & & - & \\
\hline
\end{tabular}


situation was in 2009 year.

During 2009 and 2010 in Serbia in the C09 group, the consumption of plain ACEinhibitors was dominant, and it was about 164 DDD/1000 inh/day or $82.50 \%$ of total drugs consumed in group C09. On the other hand, in Norway, in 2009 and 2010 year the consumption of plain ACE-inhibitors was approximately $45 \mathrm{DDD} / 1000 \mathrm{inh} /$ day or $34 \%$ of total drugs consumed in C09 group.

In Serbia, in the group of plain ACEinhibitors during 2009, the most used preparation was enalapril, fosinopril then, and on the third place was ramipril. In 2010, the situation has not changed much. Enalapril was left in the first place, and fosinopril, and ramipril have replaced their position.

Although the fosinopril, plain ACEinhibitor, has a high price, the consumption of this drug in Serbia is large. In 2009 this drug was on the second, in 2010 on the third place in overall consumption of plain ACE-inhibitors. In the same period, the consumption of fosinopril in Norway, as ACE-inhibitor with high price, was not detected, and the cheaper drugs such as enalapril and ramipril were dominant. The situation was similar when we looked at the consumption of fixed combination of ACE-inhibitors with diuretics. During the observed period in Norway were dominant the fixed combination of diuretics and cheaper ACE-inhibitors like enalapril and lisinopril. Other combinations in Norway haven not been present. In Serbia, the most frequently used fixed combination was enalapril with diuretcs. However, in Serbia, we have large consumption fixed combinations of diuretics with expensive ACE-inhibitors, such as cilazapril and fosinopril.

From pharmacoeconomic point of view on high consumption of expensive ACEinhibitors (plain and fixed combination with diuretics) in 2009 and 2010 in Serbia have been allocated great financial resources.

The savings would be large if the structure of consumed drugs from the group of ACE-inhibitors were as in Norway. We must stress that the saving funds would not be on the account of the quality of pharmacotherapy because it is well known that Norway is the country with a developed pharmacotherapeutical practice.

As we can see from the results of this study,the consumption of ACE-inhibitor in Serbia is very large. The question is whether such a high consumption of these drugs is justified and do these drugs have an advantages in the treatment of hypertension when we compare them with other antihypertensives. Numerous comparative randomized studies have shown that a similar reduction in blood pressure can be achieved equally effectively in any of these five groups of drugs: diuretics, $\beta$-blockers, ACE-inhibitors, calcium channel blockers or angiotensin receptor antagonists [8]. According to the recommendations of the European Society of Hypertension, the treatment of isolated systolic hypertension should in most cases start with a diuretic, which is not very oftenly used in Serbia [8]. Analysis of drug consumption in Serbia comparing with Norway, as the country with a developed pharmacotherapeutical practice, indicate that the structure of consumption of drugs from the pharmacotherapeutic point of view is not adequate and that ACE-inhibitors in the relation to the other four group of drugs have great advantage unjustifiably.

\section{CONCLUSIONS}

In Serbia, ACE-inhibitors are the most used group of drugs from all drugs which are used in the treatment of cardiovascular diseases and their share in total consumption of drugs is higher than in Norway.

The structure of most frequently used drugs in the group of ACE-inhibitors and their fixed combination with diuretics in Serbia is different from the same drugs in Norway, the country with a developed pharmacotherapeutical practice.

From the pharmacoeconomic point of view on high consumption of expensive ACE-inhibitors (plain and fixed combination with diuretics) in 2009 and 2010 in Serbia have been allocated great financial resources.

\section{ACKNOWLEDGEMENT}

This research was supported by the Provincial Secretariat for Science and Technological Development, Autonomous Province of Vojvodina, Project No 114-451-3551/2013-01, and by the Ministry of Education, Science and Technological Development, Republic of Serbia, Project No 41012. 


\section{REFERENCES}

1. Werner C, Baumhäkel M, Teo KK, Schmieder R, Mann J, Unger T, Yusuf S, Böhm M. RAS blockade with ARB and ACE inhibitors: current perspective on rationale and patient selection. Clin Res Cardiol. 2008;97(7):418-31.

2. Sabo A, Tomic Z, Stilinovic N, Milijasevic B, Mikov $M$, Vukmirovic $S$, Horvat $O$. Consumption of serum lipid-reducing drugs in Serbia compared with Scandinavian countries: a population-based study, 20042008. Pharmacoepidemiol Drug Saf. 2011;20:45-9.

3. Radonjic V, Stefanovic D, Tesic D, Djukic Lj. Analysis of trade and consumption of drugs for the treatment of cardiovascular disease in the Republic of Serbia, 2004-2007. Arhiv za farmaciju. 2008;58:372-86. (in Serbian language)

4. Bian B, Kelton CML, Guo JJ, Wigle PR. ACE inhibitor and ARB utilization and expenditures in the Medicaid Fee-For-Service Program from 1991 to 2008. J Manag Care Pharm. 2010;16(9):671-79.

5. Catic T, Begovic B. Outpatient antihypertensive drug utilization in Canton Sarajevo during five years period (2004-2008) and adherence to treatment guidelines assessment. Bosn J Basic Med Sci. 2011;11(2):97-102.

6. Stimac D, Polic-Vizintin $M$, Skes $M$, Cattunar A, Cerovic R, Stojanovic D. Utilization of cardiovascular drugs in Zagreb 2001-2005. Acta Cardiol. 2010;65(2):193-201.

7. Grilo A, Saez-Rosas MP, Santos-Morano J, Sanchez E, Moreno-Rey C, Real LM, Ramírez-Lorca R, Sáez ME. Identification of genetic factors associated with susceptibility to angiotensin-converting enzyme inhibitors-induced cough. Pharmacogenet Genomics. 2011;21(1):10-7.

8. Mancia G, De Backer G, Dominiczak A, Cifkova R, Fagard R, Germano G, Grassi G, Heagerty AM, Kjeldsen SE, Laurent S, Narkiewicz K, Ruilope L, Rynkiewicz A, Schmieder RE, Boudier HA, Zanchetti A, Vahanian A, Camm J, De Caterina R, Dean V, Dickstein K, Filippatos G, Funck-Brentano C, Hellemans I, Kristensen SD, McGregor K, Sechtem $\mathrm{U}$, Silber S, Tendera M, Widimsky P, Zamorano JL, Erdine S, Kiowski W, Agabiti-Rosei E, Ambrosioni E, Lindholm LH, Viigimaa M, Adamopoulos S, AgabitiRosei E, Ambrosioni E, Bertomeu V, Clement D, Erdine S, Farsang C, Gaita D, Lip G, Mallion JM, Manolis AJ, Nilsson PM, O'Brien E, Ponikowski P, Redon J, Ruschitzka F, Tamargo J, van Zwieten P, Waeber B, Williams B. 2007 Guidelines for the Management of Arterial Hypertension: The Task Force for the Management of Arterial Hypertension of the European Society of Hypertension (ESH) and of the European Society of Cardiology (ESC). J Hypertens. 2007;25(6):1105-87.

9. Momma K. ACE inhibitors in pediatric patients with heart failure. Paediatr Drugs. 2006;8(1):5569.

10. Amann B, Tinzmann R, Angelkort B. ACE inhibitors improve diabetic nephropathy through suppression of renal MCP-1. Diabetes Care. 2003;26(8):2421-5.

11. Radonic V, Djukic LJ. Traffic and consumption of drugs for human use in the Republic of Serbia. Belgrade: Agency for Medicines and Medical Devices of Serbia; 2007.

12. Radonic V, Djukic LJ. Traffic and consumption of drugs for human use in the Republic of Serbia. Belgrade: Agency for Medicines and Medical Devices of Serbia; 2008.

13. Radonic V, Djukic LJ. Traffic and consumption of drugs for human use in the Republic of Serbia. Belgrade: Agency for Medicines and Medical Devices of Serbia; 2009.

14. Radonic V, Djukic LJ. Traffic and consumption of drugs for human use in the Republic of Serbia. Belgrade: Agency for Medicines and Medical Devices of Serbia; 2010.

15. Radonic V, Djukic LJ. Traffic and consumption of drugs for human use in the Republic of Serbia. Belgrade: Agency for Medicines and Medical Devices of Serbia; 2011.

16. Norwegian Institute for Public Health. Drug Consumption in Norway 2008-2012. Available from: http://www. legemiddelforbruk.no/english/ [Accessed 11 May 2013].

17. Jakovljevic V, Stanulovic M, Sabo A, Mikov M. ATC Classification of Medicines with DDDs for Medicines on the Market (hard copy in Serbian language). OrtoMedics: Novi Sad, 2000. 


\section{Upotreba ACE-inhibitora u Srbiji u 2009. i 2010. godini}

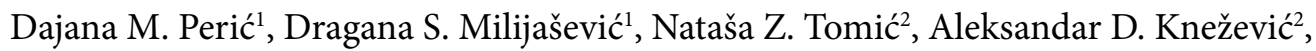
Nina R. Bukumirović́ ${ }^{1}$, Boris Ž. Milijašević ${ }^{1}$

${ }^{1}$ Katedra za farmakologiju, toksikologiju i kliničku farmakologiju, Medicinski fakultet Novi Sad, Univerzitet u Novon Sadu, Srbija;

${ }^{2}$ Urgentni centar, Klinički centar Vojvodina, Novi Sad, Srbija.

\section{KRATAK SADRŽAJ}

Uvod Kardiovaskularne bolesti (KVB) su najčešći uzrok morbiditeta i mortaliteta u velikom broju zemalja i kod nas. Zbog toga je razumljivo što su lekovi za lečenje KVB najviše korišćena grupa lekova. Cilj rada bio je da se analizira potrošnja ACEinhibitora u Srbiji i Norveškoj u 2009. i 2010. godini.

Materijal i metode Podaci o upotrebi ACE-inhibitora u Srbiji i Norveškoj za 2009. i 2010. godinu dobijeni su od Agencije za lekove i medicinska sredstva Srbije i sa sajta Norveškog instituta za narodno zdravlje.

Rezultati Upotreba lekova prvog izbora u terapiji hipertenzije u Srbiji je bila neujednačena, pri čemu je dominirala potrošnja ACE-inhibitora. Nasuprot ovoj slici u Norveškoj je potrošnja lekova prvog izbora u terapiji hipertenzije bila prilično ujednačena. Tokom obe posmatrane godine u Srbiji veliki udeo u potrošnji ACE-inhibitora činili su skuplji preparati kao što su fosinopril, cilazapril i kvinapril. U Norveškoj u posmatranom periodu dominirala je potrošnja jeftinijih preparata kao što su enalapril i ramipril. Situacija je slična kada su u pitanju fiksne kombinacije diuretika sa ACE-inhibitorima. U Norveškoj dominiraju fiksne kombinacije diuretika sa jeftinijim ACE-onhibitorima kao što su enalapril i lizinopril. Međutim, u Srbiji imamo veliku potrošnju fiksnih kombinacija diuretika sa skupim ACE-inhibitorima kao što su cilazapril i fosninopril.

Zaključak U obe države, ACE-inhibitori i njihove fiksne kombinacije sa diureticima su najviše korišćeni lekovi u okviru grupe koja se koristi za lečenje KVB u 2009. i 2010. godini. Količina i struktura potrošenih ACE-inhibitora u Srbiji u mnogome se razlikuje od količine i strukture potrošenih ACE-inhibitora u Norveškoj. Iz farmakoekonomskog ugla gledano, velika potrošnja skupih ACE-inhibitora (monokomponentnih i fiksnih kombinacija sa diureticima) u 2009. i 2010. godini imala je za posledicu veću potrošnju finansijskih sredstava.

Ključne reči: farmakoepidemiologija, ACE-inhibitori, kardiovaskularni sistem, hipertenzija 